\title{
Hydrofluoric acid burns: A case report
}

\author{
C Lukinuk BScPhm, R DasGupta MD, JL Mahoney MD FRCSC \\ Division of Plastic Surgery and Departments of Surgery and Pharmacy, St Michael's Hospital, \\ University of Toronto, Toronto, Ontario
}

\begin{abstract}
G Lukinuk, R DasGupta, JL Mahoney. Hydrofluoric acid burns: A case report. Can J Plast Surg 1997;5(3):179-180. Hydrofluoric (HF) acid has numerous uses both in industry and the home. HF burns are characterized by intense pain, progressive tissue damage and significant systemic effects. Pain may be prolonged because the fluoride ion remains active despite irrigation of the burn. Subcutaneous infiltration of calcium gluconate is the local treatment of choice. We present a case of hydrofluoric acid burn from rust remover that was effectively treated by topical calcium gluconate baths. A calcium gluconate solution can be prepared with material available in most hospitals and may be readily administered in this fashion. Early recognition and appropriate treatment of hydrofluoric acid burns will provide symptomatic relief and minimize tissue damage.
\end{abstract}

Key Words: Calcium gluconate, Hydrofluoric acid burn

\section{Brûlures à l'acide hydrofluorique : rapport de cas}

RÉSUMÉ : L'acide hydrofluorique (HF) a de nombreux usages industriels et domestiques. Les brûlures dues à l'HF sont caractérisées par une douleur intense, une lésion tissulaire progressive et des effets systémiques significatifs. La douleur peut durer un certain temps, parce que les ions fluorures restent actifs malgré l'irrigation de la brûlure. Une infiltration sous-cutanée de gluconate de calcium est le traitement local de choix. Nous présentons ici le cas d'une brûlure à l'acide hydrofluorique consécutive à l'utilisation d'un antirouille, qui a été traitée efficacement par des bains topiques de gluconate de calcium. Une solution de gluconate de calcium peut être préparée avec le matériel disponible dans la plupart des hôpitaux et s'administre facilement de cette façon. L'identification précoce et le traitement approprié des brûlures à l'acide hydrofluorique peuvent offrir un soulagement des symptômes et atténuer les lésions tissulaires.

$\mathrm{H}$ ydrofluoric (HF) acid is one of the strongest inorganic acids. It is used widely in industry in the production of plastics, germicides, solvents, fluorocarbons and semiconductors and domestically in rust removers, heavy duty cleaners and aluminum brighteners (1). Hydrofluoric acid is commonly used for etching and frosting glass. Therefore, exposure in the workplace is not uncommon.

$\mathrm{HF}$ acid burns are characterized by intense pain and severe, progressive tissue damage. If these burns are not promptly recognized and treated they may produce serious injury and prolonged disability (2). Although HF acid is a corrosive compound, the hydrogen ion plays a relatively minor role in pathogenesis. The unique nature of the burn is due to the fluoride ion, which penetrates deep tissue layers and causes liquefaction necrosis of soft tissue and corrosion of bone. The free fluoride ion also binds with the body's calcium ions, decalcifying bone and causing systemic hypocalcemia and potential cardiac arrhythmias (1).

Depletion of tissue calcium is also thought to result in cellular release of potassium from the local nerve endings, leading to severe pain. The onset and severity of both pain and tissue damage have been shown to correlate with the con-

Correspondence: Dr JL Mahoney, St Michael's Hospital, 30 Bond Street, Room 420-B, Toronto, Ontario M53 1WB, Telephone

416-864-5385, fax 416-864-5888, e-mail james.mahoney@utoronto.ca centration and amount of acid, duration of contact and location of injury (3). Solutions of up to $20 \% \mathrm{HF}$ acid may not produce erythema and pain until $24 \mathrm{~h}$ or more after exposure, while concentrations of $20 \%$ to $50 \%$ often produce symptoms 1 to $8 \mathrm{~h}$ after initial exposure (4).

The hands, specifically the subungual regions, are particularly susceptible. HF acid rapidly penetrates the subungual matrix because of the lack of stratum corneum and can destroy large portions of soft tissue and bone of the distal phalanx (5). HF easily penetrates through microscopic holes found in many protective gloves.

We present a case that illustrates both the clinical aspects and the treatment of a HF acid hand burn $48 \mathrm{~h}$ after the injury using a calcium gluconate bath as a form of noninvasive treatment.

\section{CASE PRESENTATION}

A 40-year-old male carpet layer presented to the emergency room $48 \mathrm{~h}$ after a HF acid burn. The patient had been using a rust removing agent containing $5 \% \mathrm{HF}$. He had not been wearing protective gloves because he was not aware of the potential damaging effect of HF acid. Earlier presentation at a local hospital had resulted only in treatment of symptoms with an ice and water bath.

Presenting symptoms consisted mainly of unremitting pain localized in the tips of the left index, middle, ring and 

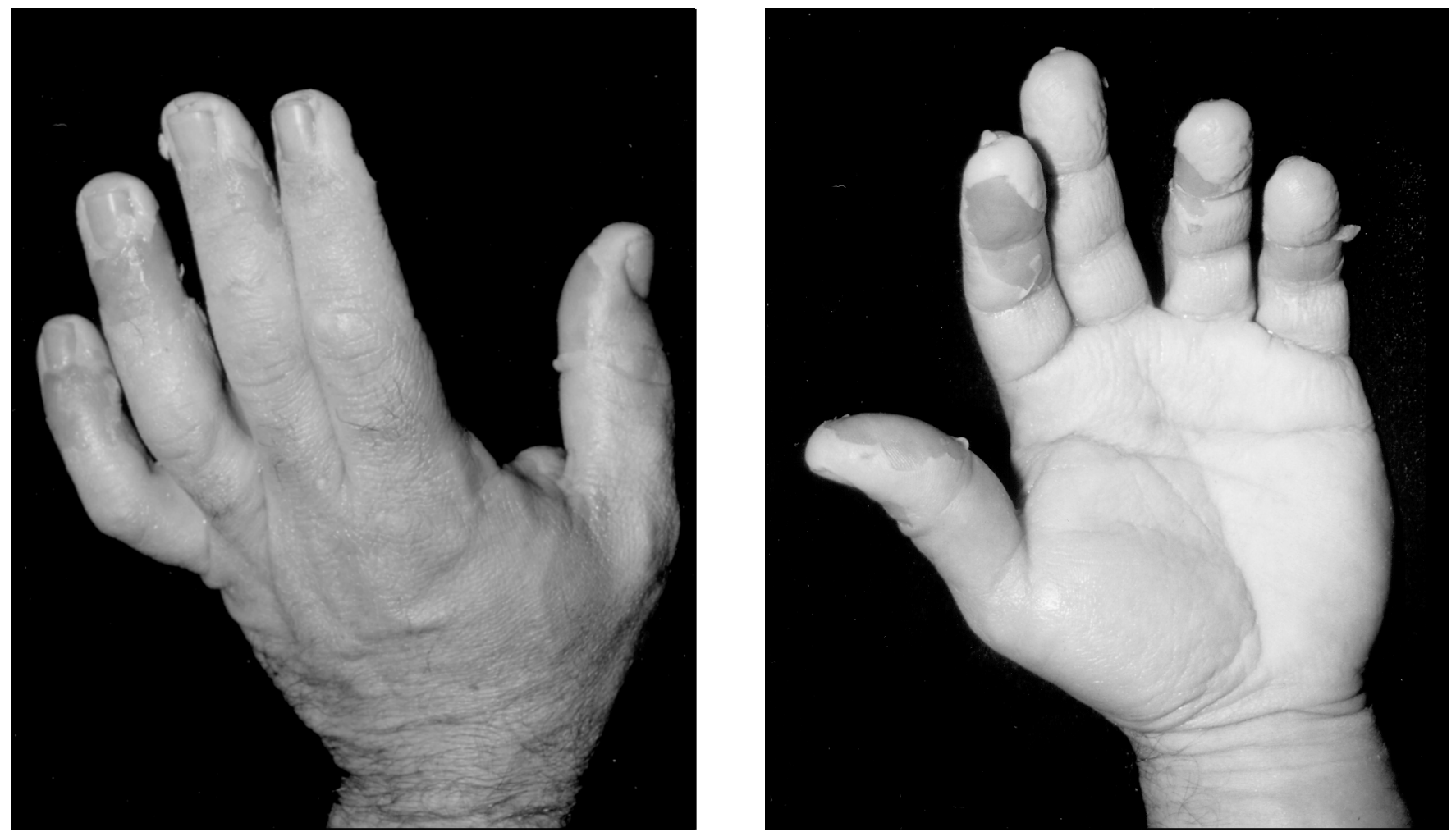

Figure 1) Appearance of fingers after treatment in a calcium gluconate bath. The extent of tissue damage is evident with blister formation and skin desquamation. Pain was relieved

small fingers. Examination revealed a slight pale discoloration, which extended from the metacarpophalangeal joints to the fingertips.

A $2.5 \%$ calcium gluconate bath was prepared by diluting readily available $10 \%$ calcium gluconate injection solution. Immersion of the patient's hand resulted in prompt pain resolution. The patient continued to soak for approximately $1 \mathrm{~h}$ and was sent home with a $2.5 \%$ calcium gluconate gel. The patient soaked his hand in a surgical glove for several hours later that evening and twice during the next day.

The patient was seen in a follow-up clinic, two days after initial presentation. Bullous changes of the skin and tissue damage, particularly around the small fingernail, were evident (Figure 1). The patient's hand was debrided and dressed until it healed. On follow-up nine months after the initial injury, all fingers and subungual areas were normal except for the small finger, where soft tissue-irregularity persisted.

\section{DISCUSSION}

The most common HF burn seen by emergency physicians results from the household use of commercial rust removal solutions or gels that contain the acid in a diluted form (less than $12 \%)(6)$, as was seen in this patient. Recommendations for initial care of HF acid dermal burns include immediate irrigation of the area with copious amounts of tepid water to dilute and remove residual acid from the skin. Following this, treatment with a calcium gluconate (7) subcutaneous injection, intra arterial infusion or topical application has proven effective, depending on the severity and location of the burn (8).
Calcium gluconate has received little attention as a topical agent. It offers the advantage of treating the same surface area that was exposed to the acid. Calcium gluconate for topical application can be prepared in two ways. A 2.5\% gel may be made by adding $3.5 \mathrm{~g}$ of calcium gluconate powder to $141.75 \mathrm{~g}$ of water-soluble surgical lubricant. However, not all hospital pharmacies or emergency departments stock calcium gluconate powder or are equipped to measure and prepare a gel with the speed required to treat a HF burn. Alternatively, calcium gluconate injection solution is commonly stocked in most hospitals and allows for easy bath preparation. Patients can comfortably soak the injured area until the pain has completely subsided.

Recognition and prompt therapy will minimize the acute discomfort and long term morbidity of HF acid burns.

\section{REFERENCES}

1. Shewmake SW, Anderson BG. Hydrofluoric acid burns. A report of a case and review of the literature. Arch Dermatol 1979;115:593-6.

2. Edinburgh M, Swift R. Hydrofluoric acid burns of the hands: A case report and suggested management. Aust NZ J Surg 1989;59:88-91.

3. Mistry D, Wainwright D. Hydrofluoric acid burns. Am Fam Physician 1992;45:1748-54.

4. Tepperman P. Fatality due to acute systemic fluoride poisoning following a hydrofluoric acid skin burn. J Occup Med 1980;22:691-3

5. Siedlicki A. Hydrofluoric acid burns. JAMA 1965;191:353.

6. MacKinnon MA. Hydrofluoric acid burns. Dermatol Clin 1988;6:67-74.

7. Upfal M, Doyle C. Medical management of hydrofluoric exposure. J Occup Med 1990;32:726-73.

8. Bertolini JC. Hydrofluoric acid: A review of toxicity. J Emerg Med 1992;10:163-8.

9. Browne TD. The treatment of hydrofluoric acid burn. J Soc Occup Med 1974;24:80-9. 